This item was submitted to Loughborough's Research Repository by the author.

Items in Figshare are protected by copyright, with all rights reserved, unless otherwise indicated.

\title{
An internet of things system for urban flood monitoring and short-term flood forecasting in Colima, Mexico
}

PLEASE CITE THE PUBLISHED VERSION

https://doi.org/10.5194/egusphere-egu2020-21079

\section{PUBLISHER}

EGU General Assembly 2020

\section{VERSION}

VoR (Version of Record)

\section{PUBLISHER STATEMENT}

This work is distributed under the Creative Commons Attribution 4.0 License (https://creativecommons.org/licenses/by/4.0/).

\section{LICENCE}

CC BY 4.0

\section{REPOSITORY RECORD}

Khouakhi, Abdou, lan Pattison, Jesús López-de la Cruz, Oliver Mendoza-Cano, Robert Edwards, Raul Aquino, Paul Lepper, et al.. 2020. "An Internet of Things System for Urban Flood Monitoring and Short-term Flood Forecasting in Colima, Mexico". Loughborough University. https://hdl.handle.net/2134/12685403.v1. 
